\title{
Hubungan Jumlah Trombosit, Hematokrit dan Hemoglobin dengan Derajat Klinik Demam Berdarah Dengue pada Pasien Dewasa di RSUP. M. Djamil Padang
}

\author{
Yobi Syumarta, Akmal M. Hanif, Erlina Rustam
}

\begin{abstract}
Abstrak
Diagnosis yang tepat terhadap stadium dan kondisi penderita DBD penting untuk menentukan prognosisnya. Pemeriksaan trombosit, hematokrit, dan hemoglobin untuk setiap derajat klinik DBD diharapkan membantu dalam mengelompokkan dan mengelola pasien berdasarkan derajat kliniknya. Penelitan ini bertujuan untuk melihat hubungan hasil pemeriksaan trombosit, hematokrit, dan hemoglobin dengan derajat klinik DBD berdasarkan kriteria WHO.Penelitian dilakukan secara retrospektif terhadap 84 sampel dari rekam medik Bagian IImu Penyakit Dalam di RSUP. M. Djamil Padang dari januari 2011 sampai 30 April 2013. Trombosit diperiksaan menggunakan metode Rees Ecker, hematokrit dengan metode langsung cara mikro, dan hemoglobin menggunakan metode Sahli. Uji hipotesis menggunakan analisis bivariat dengan uji hipotesis nonparametrik Kendal's Tau dengan software SPSS.Hasil penelitian ditemukan rerata umur $25.49 \pm 10.09$ tahun. Laki-laki 46 orang (54.8\%) lebih banyak dari wanita 38 orang (45.2\%). Hasil analisis dengan uji korelasi Kendal's Tau didapatkan trombosit berhubungan dengan derajat klinik DBD, semakin rendah trombosit semakin berat derajat kliniknya $(p<0.05, r=-0.336$ ). Hematokrit tidak berhubungan dengan derajat klinik DBD $(p>0.05, r=0.059)$. Hemoglobin tidak berhubungan dengan derajat klinik DBD $(p>0.05, r$ $=-0.036)$.Semakin rendah jumlah trombosit semakin berat derajat klinik DBD, hematokrit dan hemoglobin tidak berhubungan dengan derajat klinik DBD.
\end{abstract}

Kata kunci: jumlah trombosit, nilai hematokrit, kadar hemoglobin, derajat klinik DBD.

\begin{abstract}
Prompt diagnosis and as an accurate assessment of the stage and condition of DHF cases is a very important factor for determining patient prognosis. The existence of an exact value of the results of platelets, hematocrit, and hemoglobin for each grade of DHF are expected to greatly assist in classify and manage patients based on the clinical degree. This research was aimed to determine the relationship between the results of the hemoglobin, hematocrit and platelets count with the degree of clinical DHF according to WHO criteria. This research with retrospective design in 84 samples were taken from the medical records of adult patients in RSUP. M. Djamil Padang from 1 January 2011 until 30 April 2013. Platelets used direct method Rees Ecker, hematocrit's used direct method micro method, and hemoglobin's used Sahli method. Data processed by Kendal Tau tests using SPSS software. Results found average ages of $25.49 \pm 10,09$ years. The number of male patients 46 (54.8\%) higher than female patients 38 (45.2\%). Analysis by hypotetic test showed that there is a relationship between the platelet with clinical degree of DHF, where the lower the number, the more severe the clinical degree of $D H F(p<0.05, r=-0336)$. There is no relation between hematocrit with clinical degree of DHF ( $p>0.05, r=0.059)$. There is no relation between hemoglobin with clinical degree of $\mathrm{DHF}(p>0.05, r=-0.036)$. More lower the number of trombosit, the more severe the clinical degree of DHF, and there is no relation between hematocrit and hemoglobin with clinical degree of DHF.

Keywords: platelet count, hematocrit, hemoglobin levels, clinical degree of DHF.
\end{abstract}


Affiliasi penulis : Fakultas Kedokteran Universitas Andalas, Korespondensi : Yobi Syumarta, email:

yobi_syumarta@rocketmail.com, Telp: 085766440301

\section{PENDAHULUAN}

Indonesia merupakan salah satu negara transmisi virus dengue, dan termasuk kategori A dalam negara endemik di Asia Tenggara. ${ }^{1}$ DBD merupakan masalah kesehatan di Indonesia, ${ }^{2}$ dimana penyakit ini termasuk kedalam sepuluh penyebab perawatan di rumah sakit dan kematian pada anak-anak.

DBD pertama kali dilaporkan di Indonesia pada tahun 1968 selama wabah yang terjadi di Surabaya dan Jakarta (CFR 41,3\%) dan baru mendapat konfirmasi virologi pada tahun 1970. Di Indonesia, wabah DBD pernah dilaporkan oleh David Baylon di Batavia pada tahun 1779. ${ }^{3}$ Epidemi DBD yang terjadi pada tahun 1998, sebanyak 47.573 kasus DBD dilaporkan dengan 1.527 kematian. Kajian negara yang mendalam mengenai DBD mulai dilakukan pada bulan Juni tahun 2000, kemudian pada tahun 2004, Indonesia melaporkan CFR 1,12\% yang merupakan angka tertinggi di Asia Tenggara. ${ }^{2}$

Di kota Padang kejadian DBD pada tahun 2011 cukup tinggi dengan total sebanyak 965 kasus dan yang meninggal ada sebanyak enam kasus (CFR 0,62\%). Kejadian DBD di kota Padang mengalami penurunan dari pada tahun 2010 yang memiliki total sebanyak 1045 kasus dan meninggal sebanyak dua kasus (CFR 0.2\%). Selama 2007 sampai 2011 terjadi penurunan angka kejadian DBD di kota Padang setiap tahunnya. ${ }^{4}$

Sindrom renjatan dengue (SRD) merupakan masalah utama pada hampir seluruh pasien DBD. Sindrom renjatan dengue ini terjadi karena perembesan plasma. $^{5-7}$ Penanganan yang tepat dan seawal mungkin terhadap penderita DBD dan SRD, merupakan faktor yang penting untuk keberhasilan penanganan penderita. ${ }^{2,6,8}$

Berdasarkan pengklasifikasian keparahan demam berdarah dengue (DBD) menurut WHO tahun 1997, DBD diklasifikasikan menjadi empat derajat, yaitu derajat I, derajat II, derajat III, dan derajat IV, dimana SRD termasuk kedalam derajat III dan IV. Peningkatan permeabilitas kapiler lanjut pada stadium ini mengakibatkan perembesan plasma yang massif ke ruang interstisial yang menyebabkan hipovolemia sehingga menimbulkan berbagai manifestasi dan komplikasi yang kompleks. ${ }^{9}$

Diagnosis yang tepat dan sedini mungkin, serta penilaian yang akurat terhadap stadium dan kondisi penderita merupakan faktor yang sangat penting untuk menentukan prognosis penderita. Semakin berat penyakit penderita, semakin jelek prognosisnya. Oleh karena itu penilaian yang akurat terhadap risiko renjatan, merupakan hal yang penting untuk penatalaksanaan yang adekuat, mencegah syok dan perdarahan lanjut.

Patofisiologi utama dari DBD adalah manifestasi perdarahan dan kegagalan sirkulasi. Perdarahan biasanya disebabkan oleh trombositopaty dan trombositopenia, karena itu perlu dilakukan pemeriksaan trombosit. Peningkatan hematokrit dan hemoglobin menunjukkan derajat hemokonsentrasi, sehingga penting dalam menilai perembesan plasma. Adanya nilai yang pasti dari pemeriksaan trombosit, hematokrit dan hemoglobin untuk setiap derajat klinik DBD diharapkan sangat membantu petugas medis agar lebih mudah untuk membuat diagnosis dan menentukan prognosis dari DBD.

Kriteria WHO tahun 1997 untuk derajat klinik DBD tersebut tidak memberikan nilai yang pasti dari hasil pemeriksaan trombosit, hematokrit dan hemoglobin untuk setiap derajat kliniknya. ${ }^{9}$ Sehingga petugas medis menentukan derajat klinik tersebut hanya berdasarkan tanda dan gejala klinik saja, padahal pemeriksaan tromosit, hematokrit, dan hemoglobin memegang peranan penting untuk membantu diagnosis DBD terutama bila sudah terjadi kebocoran plasma yang dapat mencetuskan terjadinya syok.

Berdasarkan hal tersebut maka peneliti ingin melihat hubungan pemeriksaan jumlah trombosit, nilai hematokrit dan kadar hemoglobin dengan derajat klinik DBD pada pasien dewasa.

\section{METODE}

Jenis penelitian yang akan dilakukan pada penelitian tentang hubungan jumlah trombosit, hematokrit dan hemoglobin dengan derajat klinik DBD, menggunakan jenis penelitian survei analitik dengan desain penelitian retrospektif, yang bertujuan untuk memberikan gambaran hubungan hasil pemeriksaan 
jumlah hemoglobin, hematokrit, dan trombosit dengan derajat klinik DBD berdasarkan kriteria WHO. Penelitian dilakukan dibagian Rekam Medik Penyakit Dalam RSUP. M. Djamil Padang, dengan rentang waktu penelitian dari bulan Maret 2011 - Desember 2013.

Populasi penelitian adalah Semua pasien DBD dewasa yang telah didiagnosis oleh dokter penyakit dalam di bagian IImu Penyakit Dalam RSUP M. Djamil Padang pada periode 1 Januari 2011 - 30 April 2013. Sampel penelitian merupakan bagian dari populasi yang memenuhi kriteria inklusi dan eksklusi.

Kriteria inklusi penelitian Catatan rekam medik pasien DBD yang lengkap dengan usia pasien $\geq$ 16 tahun. Kriteria eksklusi adalah Pasien yang dalam riwayat pengobatan mengonsumsi obat - obat yang dapat mensupresi sumsum tulang, pasien dengan penyakit koinsiden yang lain, misalnya demam typhoid, diare berat, polisitemia vera, asidosis diabetikum, emfisema paru (stadium akhir), serangan iskemik sementara (TIA / transient ischemic attack), eklamsia, trauma, pembedahan dan luka bakar.

Variabel dan definisi operasional penelitian adalah usia, jenis kelamin, derajat klinik DBD, jumlah trombosit, hematokrit, dan hemoglobin.

Uji hipotesis menggunakan analisis bivariat dengan uji hipotesis nonparametrik Kendal Tau. Uji hipotesis ini digunakan karena variabel bebas berskala rasio, sedangkan variabel tergantung berskala ordinal. Batas kemaknaan adalah apabila $p<0,05$ yang berarti terdapat hubungan bermakna antara dua variabel yang diuji. Analisis data-data tersebut dilakukan dengan komputer menggunakan software SPSS.

Pada penelitian ini tidak dilakukan intervensi apapun pada subjek penelitian. Data berupa rekam medis pasien demam berdarah dengue dikumpulkan dari instalasi rekam medis RSUP M. Djamil Padang periode 1 Januari 2011 - 30 April 2013. Untuk memenuhi prinsip etika penelitian, kerahasiaan subjek akan tetap dijaga dengan tidak mencantumkan nama dan identitas pasien.

\section{HASIL DAN PEMBAHASAN}

Sampel penelitian diambil dari data rekam medis pasien demam berdarah dengue dikumpulkan dari instalasi rekam medis RSUP M. Djamil Padang periode 1 Januari 2011 - 30 April 2013.

Tabel 1. Kriteria Sampel Berdasarkan Derajat Klinik DBD

\begin{tabular}{ll}
\hline Derajat Klinik DBD & Jumlah $(\mathbf{N})$ \\
\hline Derajat 1 & 50 \\
\hline Derajat 2 & 28 \\
\hline Derajat 3 & 6 \\
\hline Total & 84 \\
\hline
\end{tabular}

Berdasarkan tabel 1 jumlah sampel yang diperoleh adalah sebanyak 84 orang yang memenuhi kriteria inklusi dan eklusi, dimana 50 orang berada pada derajat satu, 28 orang berada pada derajat dua, dan enam orang berada pada derajat tiga, dan tidak ditemukan derajat empat.

Tabel 2. Frekuensi usia penderita DBD

\begin{tabular}{cc}
\hline Usia & Jumlah \\
\hline$\leq 20$ & 39 \\
\hline $21-30$ & 26 \\
\hline $31-40$ & 9 \\
\hline $41-50$ & 7 \\
\hline$>50$ & 3 \\
\hline Mean \pm SD & $25.49 \pm 10.09$ \\
\hline
\end{tabular}

Berdasarkan tabel 2 kategori usia yang paling banyak menderita DBD adalah usia dibawah 20 tahun. Rerata usia penderita DBD adalah $25.49 \pm 10.09$.

Hasil ini tidak jauh berbeda dengan yang didapatkan Selvia $Y$, dimana umur rata-rata penderita DBD adalah 25.03 $\pm 7.98 .^{10}$ Jaya I (2008) di Surakarta mendapatkan umur rata-rata penderita DBD $24.40 \pm 9.31 .^{11}$

Tabel 3. Frekuensi jenis kelamin penderita DBD

\begin{tabular}{lll}
\hline Jenis Kelamin & Jumlah & Persentase \\
\hline Laki-laki & 46 & 54.8 \\
\hline Perempuan & 38 & 45.2 \\
\hline Total & 84 & 100 \\
\hline
\end{tabular}

Pada tabel 3 dapat dilihat Penderita DBD berjenis kelamin laki-laki sebanyak 46 orang (54.8\%) 
dan perempuan sebanyak 38 orang (45.2\%). Rasio penderita DBD laki-laki dengan perempuan adalah $1.21: 1$

Hal ini sesuai dengan penelitian penelitian Selvia Y pada tahun 2005 yang mendapatkan penderita laki-laki $55 \%$ dan wanita $45 \% .{ }^{10}$ Penelitian lain yang dilakukan Jaya I pada tahun 2008 juga mendapatkan hasil yang sama, yaitu laki-laki 55\% dan wanita $45 \%{ }^{11}$ Penelitian yang dilakukan oleh Depkes tahun 2008 menyatakan bahwa jumlah penderita DBD berjenis kelamin laki-laki sebesar $53,78 \%$ dan wanita sebesar $46,23 \%$. $^{12}$

Tabel 4. Hubungan trombosit dengan derajat klinik DBD

\begin{tabular}{lc}
\hline Derajat Klinik DBD & $\begin{array}{c}\text { Jumlah Trombosit } \\
\left.\text { (ribu/mm }{ }^{3}\right)\end{array}$ \\
\hline 1 & $62.64 \pm 3.63$ \\
\hline 2 & $31.14 \pm 2.25$ \\
\hline 3 & $36.17 \pm 2.29$ \\
\hline Uji korelasi Kendall's Tau & $P<0.05 \quad r=-0.336$
\end{tabular}

Berdasarkan tabel 4 didapatkan rerata jumlah trombosit pada derajat klinik 1 adalah $62.64 \pm 3.63$ $\mathrm{ribu} / \mathrm{mm}^{3}$. Rerata jumlah trombosit pada derajat klinik 2 adalah $31.14 \pm 2.25 \mathrm{ribu} / \mathrm{mm}^{3}$. Rerata jumlah trombosit pada derajat klinik 3 adalah $36.17 \pm 2.29 \mathrm{ribu} / \mathrm{mm}^{3}$. Hasil analisis dengan uji korelasi Kendall's tau didapatkan nilai $\mathrm{p}<0.05$ yang berarti terdapat hubungan yang bermakna antara jumlah trombosit dengan derajat klinik DBD. Dengan koefisien korelasi $r$ $=-0.336$ yang berarti kekuatan hubungan lemah dengan arah hubungan negatif. Sehingga dapat disimpulkan bahwa terdapat hubungan bermakna antara jumlah trombosit dengan derajat klinik DBD, dimana semakin rendah jumlah trombosit maka semakin parah derajat kliniknya.

Grafik 1 menunjukkan hubungan jumlah trombosit dengan derajat klinik DBD, dimana makin rendah jumlah tombosit makin tinggi derajat klinik DBD. Secara statistik hubungan bermakna dengan $p<$
0.05 dan $r=-0.336$

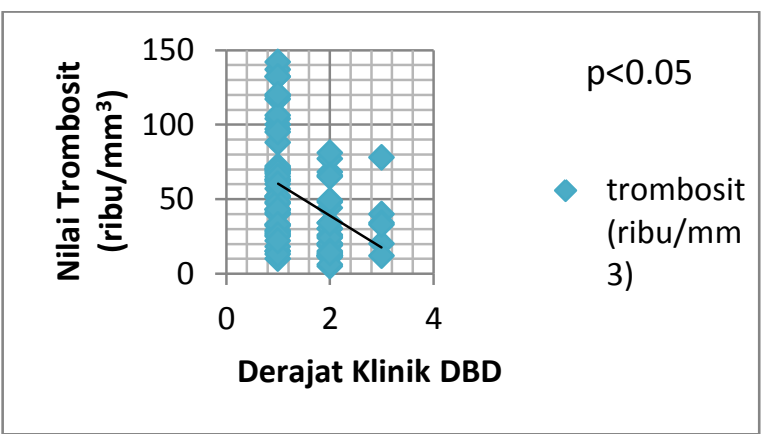

Grafik 1. hubungan jumlah trombosit dengan derajat klinik DBD

Hal ini sesuai dengan penelitian yang dilakukan Valentino Bima pada 2012 menyatakan hal yang sama bahwa terdapat hubungan yang bermakna antara jumlah trombosit dengan derajat keparahan DBD $(p<0.001) .^{13}$

Tabel 5. Hubungan hematokrit dengan derajat klinik DBD

\begin{tabular}{lll}
\hline Derajat Klinik DBD & \multicolumn{2}{l}{ Nilai Hematokrit(\%) } \\
\hline 1 & $44.22 \pm 5.59$ & \\
\hline 2 & $46.90 \pm 5.50$ & \\
\hline 3 & $38.47 \pm 7.48$ & \\
\hline $\begin{array}{l}\text { Uji } \quad \text { korelasi } \\
\text { Kendall's Tau }\end{array}$ & $\mathrm{p}>0.05$ & $\mathrm{r}=0.059$ \\
\hline
\end{tabular}

Tabel 5 memperlihatkan rerata jumlah hematokrit pada derajat klinik 1 adalah $44.22 \pm 5.59 \%$. Rerata jumlah hematokrit pada derajat klinik 2 adalah $46.90 \pm 5.50 \%$. Rerata jumlah hematokrit pada derajat klinik 3 adalah $38.47 \pm 7.48 \%$. Hasil analisis dengan uji korelasi Kendall's tau didapatkan nilai $r=0.059$ yang berarti kekuatan hubungan sangat lemah dengan arah hubungan positif dan nilai $p>0.05$ yang berarti tidak terdapat hubungan bermakna antara nilai hematokrit dengan derajat klinik DBD. Sehingga dapat disimpulkan bahwa tidak terdapat hubungan bermakna antara nilai hematokrit dengan derajat klinik DBD. 
Grafik 2 menunjukkan hubungan nilai hematokrit dengan derajat klinik DBD, dimana secara statistik tidak didapatkan hubungan yang bermakna dengan $p>0.05$ dan $r=0.059$.

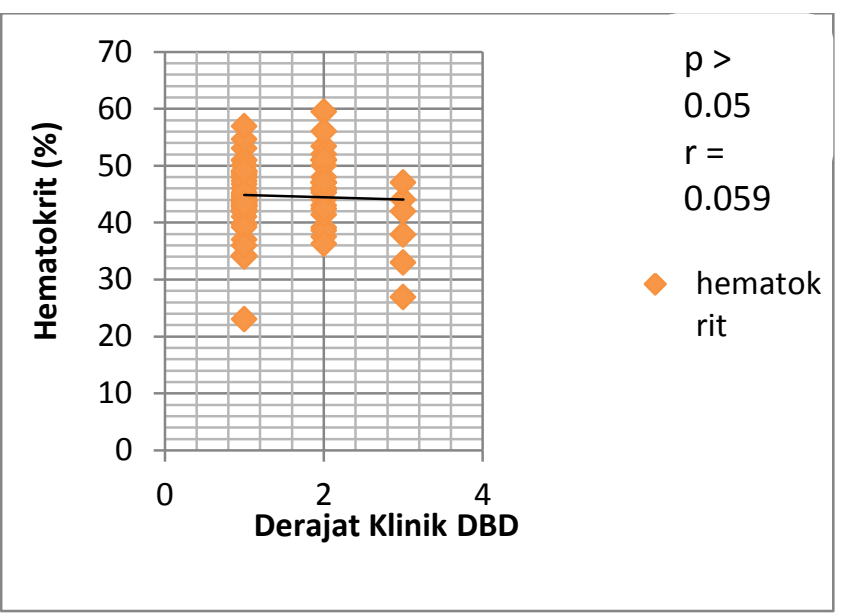

Grafik 2. hubungan nilai hematokrit dengan derajat klinik DBD

Hal yang sama juga didapatkan dari penelitian Jaya I pada tahun 2008 bahwa nilai hematokrit tidak berhubungan dengan derajat klinik DBD dengan nilai $p>0.05$ dan $r=-0.070 .^{11}$ Penelitian lain yang dilakukan oleh Valentino Bima juga menunjukkan hal yang sama, dengan nilai $p=0.060$ dan $r=0.049 .^{13}$

Hasil penelitian Nurhayati di tahun 2004, menunjukkan bahwa penelitian terhadap kadar hematokrit, nampak signifikan berhubungan dengan SRD dalam pengukuran puncak kadar hematokrit atau merupakan kadar hematokrit pada saat terjadinya puncak penyakit saja. ${ }^{14}$

Temuan ketiga peneliti tersebut di atas juga menegaskan hasil yang didapatkan oleh penelitian ini, bahwa kadar hematokrit awal dan derajat klinis DBD tidak berhubungan dengan signifikan. Kadar hematokrit awal tidak berhubungan dengan derajat klinis DBD, sementara kadar hematokrit puncak berhubungan, maka peningkatan kadar hematokrit dimungkinkan bukan merupakan faktor awal yang dominan dalam patogenesis DBD, namun sekadar merupakan variabel lanjut dalam perjalanan penyakit.

Tabel 6. Hubungan hemoglobin dengan derajat klinik DBD

\begin{tabular}{|c|c|}
\hline Derajat Klinik DBD & Kadar Hemoglobin (gr/dl) \\
\hline 1 & $14.88 \pm 1.76$ \\
\hline 2 & $15.14 \pm 2.13$ \\
\hline 3 & $12.96 \pm 2.51$ \\
\hline $\begin{array}{lll}\text { Uji } & \text { korelasi Kendall's } \\
\text { Tau } & & \end{array}$ & $p>0.05$ \\
\hline
\end{tabular}

Berdasarkan tabel 6 didapatkan rerata jumlah trombosit pada derajat klinik $114.88 \pm 1.76 \mathrm{gr} / \mathrm{mm}^{3}$. Rerata jumlah trombosit pada derajat klinik 2 adalah $15.14 \pm 2.13 \mathrm{gr} / \mathrm{mm}^{3}$. Rerata jumlah trombosit pada derajat klinik 3 adalah $12.96 \pm 2.51 \mathrm{gr} / \mathrm{mm}^{3}$. Hasil analisis dengan uji korelasi Kendall's tau didapatkan nilai $r=-0,036$ yang berarti kekuatan hubungan sangat lemah dengan arah hubungan negatif dan nilai $p>0.05$ yang berarti tidak terdapat hubungan bermakna antara kadar hemoglobin dengan derajat klinik DBD. Sehingga dapat disimpulkan bahwa tidak terdapat hubungan bermakna antara kadar hemoglobin dengan derajat klinik DBD.

Grafik 3 memperlihatkan hubungan kadar hemoglobin dengan derajat klinik DBD, dimana secara statistik tidak ditemukan hubungan yang bermakna dengan $p>0.05$ dan $r=-0.038$.

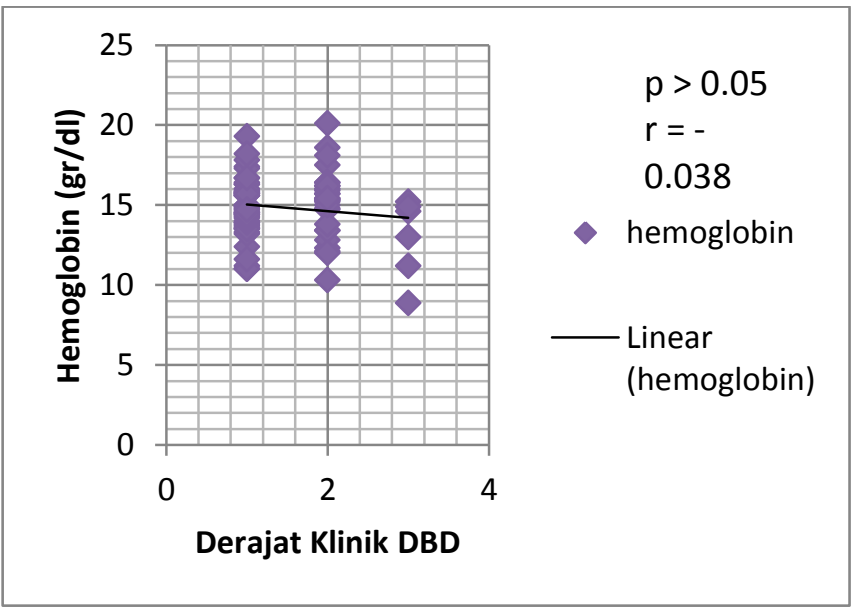

Grafik 3. hubungan kadar hemoglobin dengan derajat klinik DBD 
Hasil penelitian ini sesuai dengan hasil penelitian yang didapatkan oleh Valentino Bima di tahun 2012, yaitu: nilai $p=0.759$ dan $r=0.029$ yang berarti kadar hemoglobin dengan derajat klinik DBD tidak berhubungan secara bermakna. ${ }^{13}$

Dalam penelitian ini terlihat kadar hemoglobin dua orang pasien berjenis kelamin laki-laki pada derajat 3 yang mengalami penurunan. Kadar hemoglobin pasien laki-laki tersebut adalah $11.2 \mathrm{gr} / \mathrm{dl}$ dan $8.86 \mathrm{gr} / \mathrm{dl}$. Kadar hemoglobin pasien tersebut juga memperlihatkan kesesuaian dengan penurunan jumlah hematokrit berturut-turut $33 \%$ dan $26.9 \%$ (nilai rujukan $42 \%-54 \%$ ). Hal tersebut sesuai dengan pernyataan sebelumnya yang menunjukkan bahwa kadar hemoglobin mengikuti perubahan pada nilai hematokrit.

\section{KESIMPULAN}

1. Terdapat hubungan yang bermakna jumlah trombosit dengan derajat klinik DBD pada pasien dewasa, dimana semakin rendah jumlah trombosit maka semakin berat derajat kliniknya.

2. Tidak terdapat hubungan yang bermakna nilai hematokrit dengan derajat klinik DBD pada pasien dewasa.

3. Tidak terdapat hubungan yang bermakna kadar hemoglobin dengan derajat klinik DBD pada pasien dewasa.

\section{DAFTAR PUSTAKA}

1. World Health Organisation. Regional Office for South East Asia. Variable endemicity for DF/DHF in countries of SEA Region. 2007 (diakses pada tanggal 14 Januari 2013 jam 14.00 WIB) www.searo.who.int

2. Ganda IJ. Comparison of blood gases analysis in patients with DSS and DHF. J Med Nus Vol. 27. 2006 (diakses pada tanggal 11 November 2012 jam 22.30 WIB) http://med.unhas.ac.id

3. Hassan $R$, Alatas $H$, editor. Dengue, in: Buku kuliah IKA 2. cet.11. Jakarta: Bag. IKA FKUI. 2005.

4. Dinas Kesehatan Kota Padang. Laporan tahunan tahun 2011. Edisi 2012.
5. Soedarmo SSP. Demam berdarah dengue pada anak. Cetakan ke-2. Jakarta: Penerbit Universitas Indonesia. 2005.

6. "PAPDI Forum: Penatalaksanaan DBD". Berita Ikatan Dokter Indonesia. Maret-April 2007, III: 101.

7. Nurhayati D. Perbedaan nilai maksimum dan minimum protein plasma, hematokrit, dan trombosit terhadap awal kejadian syok penderita DBD di instalasi kesehatan anak RS DR. Sardjito. PPDS 1 Tesis. 2004 (diakses pada tanggal 12 Januari 2013 jam 15.00 WIB) http://puspasca.ugm.ac.id

8. Soegijanto S. Patogenesa dan perubahan patofisiologi infeksi virus dengue. 2006. (diakses pada tanggal 18 November 2012 jam 16.00 WIB) www.dexa-medica.com

9. World Health Organisation. Dengue haemorrhagic fever: diagnosis, treatment, prevention and control. 2nd edition. Geneva. 1997 (diakses pada 25 January 2013 jam 23.00 WIB) www.who.int

10. Selvia Y. Hubungan gambaran klinis demam berdarah dengue dengan serotipe virus dengue pada penderita yang dirawat di bangsal penyakit dalam di beberapa rumah sakit di Kota Padang. Tesis Akhir Program Studi Penyakit Dalam FKUA/RS. M. Djamil. 2005.

11. Jaya I. Hubungan kadar hematokrit awal dengan derajat klinis demam berdarah dengue. Skripsi Akhir FK Muhammadiyah Surakarta. 2008.

12. Departemen Kesehatan. "Demam berdarah dengue", Buletin jendela epidemiologi. 2010 (diakses pada tanggal 2 September 2013 jam 20.00 http://www.depkes.go.id/downloads/publikasi/bul etin/BULETIN\%20DBD.pdf

13. Valentino B. Hubungan antara hasil pemeriksaan darah lengkap dengan derajat klinik infeksi dengue pada pasien dewasa di RSUP Dr. Kariadi Semarang. FK Universitas Diponegoro. Semarang. 2012.

14. Nurhayati D. Perbedaan nilai maksimum dan minimum protein plasma, hematokrit, dan 
trombosit terhadap awal kejadian syok penderita

DBD di instalasi kesehatan anak RS DR.

Sardjito. PPDS 1 Tesis. 2004 (diakses pada 17 $\begin{array}{llll}\text { January } & 2013 \quad \text { jam } & 16.00 \quad \text { WIB) }\end{array}$

http://puspasca.ugm.ac.id 